\title{
Characterization of Eggshell: A Heterogeneous Catalyst in Transesterification of Sand Apple (Parinari polyandra) Seed Oil
}

\author{
${ }^{1}$ ONIYA, OO; ${ }^{2 * S A L E H, ~ A ; ~}{ }^{1}$ AKANDE, FB; ${ }^{3}$ ADEYEMI, DT \\ ${ }^{1}$ Department of Agricultural Engineering, Ladoke Akintola University of Technology, Ogbomoso, Nigeria \\ ${ }^{* 2}$ Dept. of Agricultural \& Bio-Resources Engineering, Ahmadu Bello University, Zaria, Nigeria \\ ${ }^{3}$ National Centre for Agricultural Mechanization, Ilorin, Nigeria \\ *Corresponding Author Email: salehaminu@gmail.com; Tel: +2348035774780
}

\begin{abstract}
The objective of this study was to characterize a low cost heterogeneous catalyst from the transesterification of sand apple (parinari polyandra B.) biodiesel. Sand apple fruits were processed and oil was extracted using solvent extraction method. Raw eggshells were calcined at $800^{\circ} \mathrm{C}$ for $120 \mathrm{~min}$ in the muffle furnace. Surface properties of the raw and calcined eggshell were characterized using Fourier Transformed Infrared Radiation (FTIR) and X-Ray Fluorescence (XRF). Transesterification of the Sand Apple Oil (SASO) with ethanol in the presence of the calcined catalyst to produce ethyl ester and glycerol were optimized using Central Composite Design at different temperatures and time. Reactants for the transesterification process were the raw SASO and anhydrous ethanol. The study shows that raw eggshell was more stable with hydrogen bond form at $2,724 \mathrm{~cm}^{-1}$ an while oil yield of $53.13 \%$ was obtained from sand apple kernels. Ethyl ester yield of $90 \%$ was obtained from SASO. The results of transesterification shows the maximum biodiesel yield of $90 \%$ was obtained at reaction temperature of $65^{\circ} \mathrm{C}$ and time of $120 \mathrm{~min}$, while the minimum yield of $70 \%$ was obtained at temperature of $55^{\circ} \mathrm{C}$ and time of $60 \mathrm{~min}$; indicating that biodiesel increase with increase in time. Similarly, yield of ethyl ester of SASO also increased when the reaction temperature increased. The percentages of biodiesel yield obtained from SASO transesterification in this study showed that sand apple is promising oil for biodiesel production as compared with other vegetable oil crop obtained in previous studies
\end{abstract}

\section{DOI: https://dx.doi.org/10.4314/jasem.v25i7.12}

Copyright: Copyright $\odot 2021$ Oniya et al. This is an open access article distributed under the Creative Commons Attribution License (CCL), which permits unrestricted use, distribution, and reproduction in any medium, provided the original work is properly cited.

Dates: Received: 10 May 2021; Revised: 28 June 2021; Accepted: 01 July 2021

Keywords: Biodiesel, Ethyl-Ester, Transesterification, Blend, Oil yield

Biodiesel is commonly produced by transesterification of vegetable oil or animal fat feedstock (Oniya and Bamgboye, 2014). Chemically, transesterified biodiesel comprises a mix of mono-alkyl esters of long chain fatty acids. Using alcohols of higher molecular weights improves the cold flow properties of the resulting ester, at the cost of a less efficient transesterification reaction. A lipid trans-esterification production process is used to convert the base oil to the desired esters. Any free fatty acids (FFAs) in the base oil is either converted to soap or removed from the process, or they are esterified (yielding more biodiesel) using an acidic catalyst. After this process, unlike straight vegetable oil, biodiesel has combustion properties very similar to those of petroleum diesel that could replace it in most current uses. A by-product of the trans-esterification process is the glycerol (Wei et al., 2004). Usually, crude glycerol has to be purified, typically by performing vacuum distillation. The refined glycerol $(98 \%$ + purity) can then be utilized directly or converted into other products (Kusdiana $e t$ al., 2007). A catalyst is a substance that increases the rate of chemical reaction (catalytic force) without itself undergoing any permanent chemical change
(Shruti et al., 2012). It is capable of accelerating the reaction rate or to change the selectivity of the reaction, toward different product with respect to the situation when the reaction occurs in the absence of the catalyst. The role of catalyst is therefore to reduce the activation energy by providing another pathway for the reaction to occur so that the catalytic agent makes the reaction proceed faster and at lower temperature than non-catalyzed reaction. Catalysts are distinguished into homogeneous and heterogeneous (Shruti, et al. 2012). Where the reaction occurs in the same phase it is referred as homogeneous but becomes heterogeneous if it is in different phases. Most of the processes using homogeneous catalysts occur in liquid form, while heterogeneous catalyst is always in solid form. Heterogeneous catalyst has a major advantage over the homogenous because the catalyst can be separated by simple filtration and re-utilized at the end of reaction for the next reaction (Vyas, et al. 2009). Heterogeneous catalyst has good thermal stability, environmentally friendly, reusability, simple and cheaper compared to homogeneous catalyst. The thrust of this study was, therefore, to characterize heterogeneous catalyst (eggshell) from the

*Corresponding Author Email: salehaminu@gmail.com; Tel: +234803 5774780 
transesterification of biodiesel obtained from sand apple (parinari polyandra B.)

\section{MATERIALS AND METHODS}

Materials used in this study include Sand apple fruits Eggshell, Muffle furnace, anhydrous ethanol, magnetic stirrer, reagents, mortar and pestle and $2 \mathrm{~mm}$ sieve, and Spectrophotometer.

Preparation of Catalyst from Eggshell: Broken eggshells were collected from Uncle Willy bakery in Ilorin, Kwara State, Nigeria. The eggshells were washed and sun-dried on a platform for $1 \mathrm{~h}$. They were then grounded using mortar and pestle and sieved with $2 \mathrm{~mm}$ size. $180 \mathrm{~g}$ of dried ground egg shell was measured into crucibles and put in a muffles furnace and subjected to high temperature above $800{ }^{\circ} \mathrm{C}$ for $2 \mathrm{~h}$ to transform the calcium in the shell into calcium oxide $(\mathrm{CaO})$ as recommended by Niju et al. (2014). A sample in crucible was removed from muffles furnace after $24 \mathrm{~h}$ of cooling and placed in an air tight container to prevent oxidation. The characterization of the raw and calcined eggshell was determine using Fourier Transformed Infrared Radiation (FTIR) and X-Ray Fluorescence (XRF) analyses in order to determined their surface characteristics and oxide composition, respectively as recommended by Feunte et al. (2003).

Buck scientific model, M530 Quick Scan Dispersive Infrared Spectrophotometer was used for FTIR analysis. The raw and calcined eggshell samples were crushed with potassium bromide ( $\mathrm{KBr})$. The product was introduced into the equipment with sample holder; the spectra was displayed on the screen and printed out (Feunte et al., 2003). For X- Ray fluorescence, Thermo Scientific XRF (Niton XL3t model) was used. Sample of powdery eggshell was poured into vial and closed with foil leather then placed on the sample holder stand. An analyzer was set to $\mathrm{Cu} / \mathrm{Zn}$ method then placed tightly on the sample vial and the reading button was pressed for $30 \mathrm{sec}$., then reading was taken. The analyzer automatically produced both the result and spectra and noted them on the computer attached.

Production of Biodiesel from Sand Apple Seed Oil (SASO): Biodiesel was produced from SASO by transesterification reaction. The reactants for the transesterification process were the raw SASO, anhydrous ethanol and calcined eggshell which was used as catalyst. Variables taken into consideration for the reaction were reaction temperature and reaction time. The experiments were conducted with temperatures ranged from $55-65^{\circ} \mathrm{C}$ which are below the boiling point of ethanol. A maximum temperature of $65^{\circ} \mathrm{C}$ was adopted for the reaction temperature as recommended by Alamu et al. (2007). Reaction time used ranged from 60 to $120 \mathrm{~min}$, which were enough to allow perfect contact between the reagents and the oil during transesterification as the reaction mixture was continuously stirred at a constant rate. The transesterification reaction involved the use of 12 moles of alcohol to 1 mole of oil and this is more than the standard 3:1 alcohol to oil stoichiometric requirement. The reason for this is that the reaction was desired to proceed in the forward direction by shifting the equilibrium to the right as recommended by Gerpen et al. (2004). Catalyst concentration used was $6 \%$ by weight of the SASO. All these reaction conditions were based on the conditions of seed oil transesterification using heterogeneous catalysts derived from eggshells as suggested by Wei et al. (2004).

A constant volume of $70 \mathrm{ml}$ of SASO was pre-heated and measured into the reactor (Roger et al., 2005). $7 \mathrm{~g}$ of catalyst was mixed with $55 \mathrm{ml}$ of ethanol and stirred vigorously. Thereafter, the formed product was swiftly introduced into the oil on the reactor and stirred vigorously for $2 \mathrm{~h} .15 \mathrm{~min}$. to the end of the reaction, $14 \mathrm{ml}$ of distilled water (20\% of initial volume of oil) was added to the mixture and stirred continued for next $15 \mathrm{~min}$ to aid formulation and easy separation of biodiesel as recommended by Oniya and Bamgboye (2014). The mixture was thereafter poured inside a separating funnel and allowed to stand for $24 \mathrm{~h}$, glycerol which is a heavier liquid settled at the bottom and ethyl ester, which is lighter, was at the top (Figure 1). The glycerol was decanted in a container and biodiesel was stored in a sample bottle.

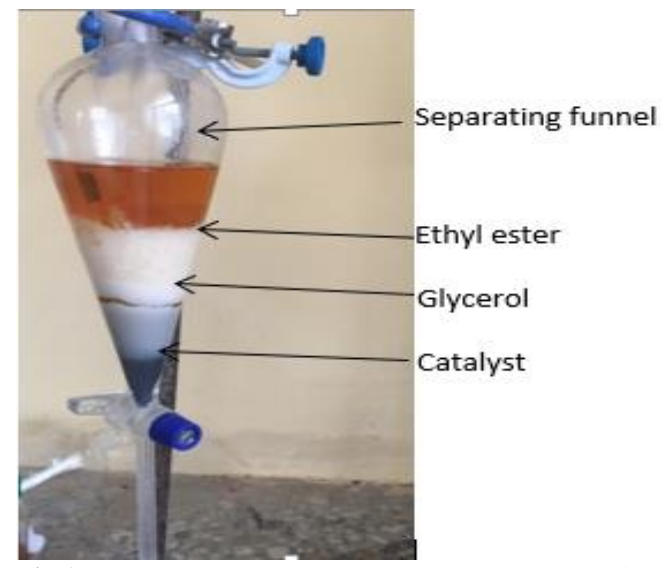

Fig 1: Separation of ethyl ester and glycerol obtained from transesterification process

Biodiesel product was washed with distilled water at $30 \%$ of the ester volume. The mixture was stirred vigorously with mechanical stirrer. Stirring was stopped after $10 \mathrm{~min}$ and poured into separating funnel 
for the next $48 \mathrm{~h}$, the unreacted ethanol and glycerol that are present were decanted. It was washed three times to obtain a pure ethyl ester sample. Biodiesel produced was heated to $105^{\circ} \mathrm{C}$ for $20 \mathrm{~min}$ to remove any water present and then stored for further analysis. The percentage of ester yield from sand apple was determined using Equation 1 as recommended by Oniya (2010).

$$
Y=\frac{V_{e}}{V_{r}} \times 100 \%
$$

Where: $Y=$ yield of ethyl ester $(\%) ; V_{e}=$ volume of ethyl ester produced $\left(m^{3}\right) ; V_{r}=$ volume of raw oil used $\left(m^{3}\right)$

Experimental Design: Central Composite Design (CCD) under Response Surface Methodology (RSM) in the Design Expert Software 6.0.8 was used to evaluate yield of SASO produced. Dependent variable considered for this study was biodiesel yield (Y1) while independent variables were temperature $(\mathrm{A})$ and time (B) obtained from transesterification experiments of the SASO using calcined eggshell as catalyst were analyzed statistically. Analysis of Variance (ANOVA) was used to evaluate whether there is significant difference between the means of the values of reaction parameters at 5\% probability level on biodiesel yield. Thirteen (13) experimental runs were generated at random from the experimental design. The central composite design layout for biodiesel production is shown in Table 1 while Table 2 shows factors level selected for the transesterification experiment. Maximum yield was used to determine the optimum condition for the transesterification factors at a particular contact time, agitation rate and concentration. One -factor-at- a- time method was used to study the effect of factors after obtaining the optimum condition.

Table 1: Central Composite Design Layout for Biodiesel

\begin{tabular}{llll}
\hline \multicolumn{3}{c}{ Production } \\
\hline 1 & $\begin{array}{l}\text { Factor } \\
\text { Temperature } \\
\left({ }^{\circ} \mathrm{C}\right)\end{array}$ & $\begin{array}{l}\text { Factor B } \\
\text { time } \\
(\mathbf{m i n})\end{array}$ & $\begin{array}{l}\text { Response } \\
\text { biodiesel } \\
\text { yield \% }\end{array}$ \\
\hline 25.00 & 60 & \\
3 & 55.00 & 60 & \\
4 & 55.00 & 60 & \\
5 & 60.00 & 90 & \\
6 & 60.00 & 90 & \\
7 & 60.00 & 90 & \\
8 & 60.00 & 90 & \\
9 & 55.00 & 60 & \\
10 & 65.00 & 120 & \\
11 & 65.00 & 90 & \\
12 & 60.00 & 60 & \\
13 & 60.00 & 90 & \\
\hline
\end{tabular}

The effect of the reaction temperature from 55 $65^{\circ} \mathrm{C}$ on the yield of the SASO was investigated with the optimum value of obtained at interval of $5^{\circ} \mathrm{C}$ Effect of the reaction time from $60-120 \mathrm{~min}$ on the yield of SASO was also investigated with the optimum value obtained at interval of $30 \mathrm{~min}$.

Table 2: Factors Level Selected for Tranesterification

\begin{tabular}{llll}
\hline Factors & Units & \multicolumn{2}{c}{ Level } \\
\cline { 3 - 4 } & & Low & High \\
\hline Temperature & ${ }^{\circ} \mathrm{C}$ & 55 & 65 \\
Time & Min & 60 & 120 \\
\hline
\end{tabular}

Development of Blends of Sand Apple Biodiesel with $A G O$ : Petroleum diesel fuel otherwise known as Automotive Gas Oil (AGO) used in the blends was obtained from NNPC fuel station, Ogbomoso. Biodiesel blends were produced from SASO blended with petroleum diesel fuel in volume basis. The blending ratios are:

i) Biofuel at $5 \%$ of SAEE and $95 \%$ AGO by volume, (B5)

ii) Biofuel at $10 \%$ of SAEE and $90 \%$ AGO by volume, (B10)

iii) Biofuel at $15 \%$ of SAEE and $85 \%$ AGO by volume, (B15)

iv) Biofuel at $20 \%$ of SAEE and $80 \%$ AGO by volume, (B20)

v) Biofuel at $25 \%$ of SAEE and $75 \%$ AGO by volume, (B25)

\section{RESULTS AND DISCUSSION}

Characterization of Eggshell using FTIR and XRF: The FTIR analysis of the raw eggshell and calcined eggshell are shown in Figure 2 (a) and (b), respectively. Prominent peaks identified on the spectra of the raw and calcined eggshell are presented respectively in Tables 3 and 4. The peaks observed in the raw eggshell ranges from $638.5-3891.0 \mathrm{~cm}^{-1}$ and percentage transmittance ranged between 5 and $20(\%$ $\mathrm{T})$, while the peaks observed in the calcined eggshell ranges from $646.4-3871.0 \mathrm{~cm}^{-1}$ and their percentage transmittance ranges between 20 and $60(\% \mathrm{~T})$. Also the wave number ranges from $1000 \mathrm{~cm}^{-1}-4000 \mathrm{~cm}^{-1}$. Different types of bonds such as $\mathrm{O}-\mathrm{H}$ stretching vibration, $\mathrm{C}-\mathrm{H}$ stretching vibration $\mathrm{C}=\mathrm{C}$ vibration and $\mathrm{C}-\mathrm{C}$ vibration, $\mathrm{C} \equiv \mathrm{C}$. The $\mathrm{C}=\mathrm{O}$ stretching is of lactone, ketones and carboxylic anhydrides. Infrared of the raw eggshell peak at $3616 \mathrm{~cm}^{-1}$ was unstable with $\mathrm{O}-\mathrm{H}$ stretching vibration due to the presence of carboxylic compound and high amount of protein. Reverse was the case for calcined egg shell, Figure 2 (b), which has a stable condition with strong intensity of $\mathrm{OH}$ up to the state of $3342 \mathrm{~cm}^{-1}$ that has weaker intensity and less broad band than $\mathrm{O}-\mathrm{H}$ and amine. At 3,000-2,850 cm ${ }^{1}$, the calcined eggshell has carbon which is hybridized with convenient dividing line between $\mathrm{C}-\mathrm{H}$ stretching vibration bond and preceding type but in raw eggshell, 
the $\mathrm{C}-\mathrm{H}$ bond was medium. Vibration were observed to occur between the bands.
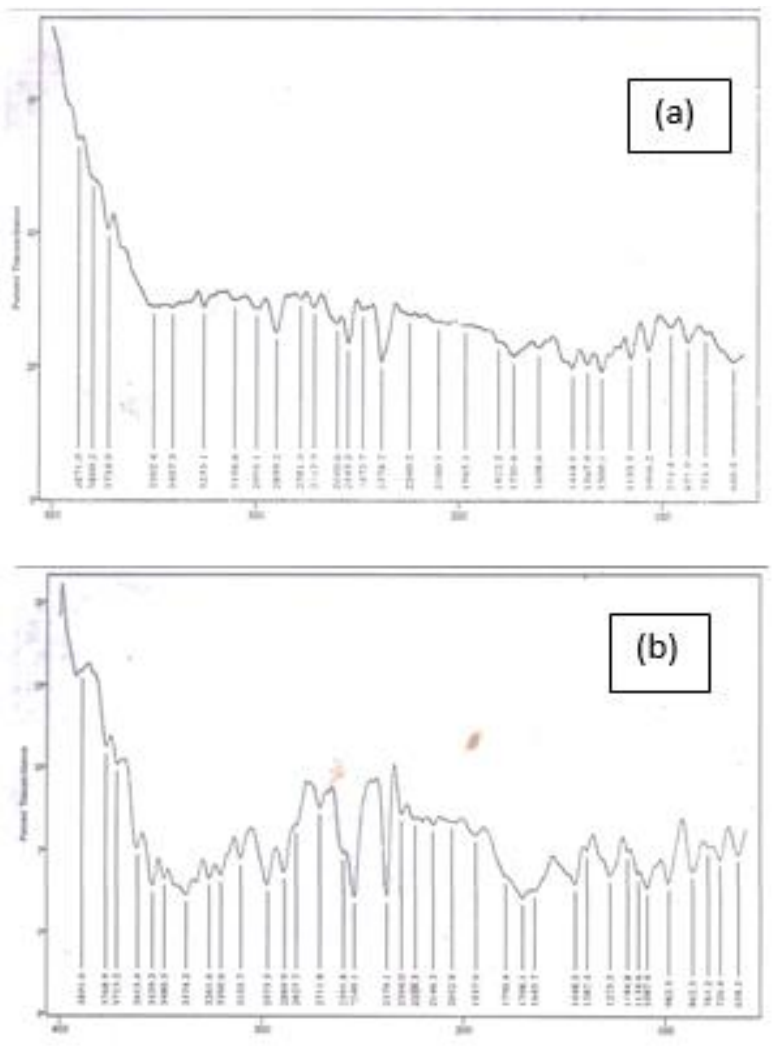

Fig 2: (a) Raw eggshell spectra and (b) Calcined eggshell spectra
Raw eggshell was more stable with hydrogen bond form at $2,724 \mathrm{~cm}^{-1}$ with a dipolar group having large amount of protein but in calcined eggshell, the protein had been vapourized and weak. From 1,645.7-1,608.6 $\mathrm{cm}^{-1}$ the spectra shows the presence of strong intensity in both raw sample and calcined eggshell with presence of carbon to carbon double bond noted. At $1,614,1,506$ and $1,465 \mathrm{~cm}^{-1}$ carbon to carbon vibration in the aromatic ring with $\mathrm{C}-\mathrm{H}$ bending and $\mathrm{C}-\mathrm{H}$ loop at $638 \mathrm{~cm}^{-1}$. The disappearance of $\mathrm{O}-\mathrm{H}$ stretching in the calcined sample indicated the water molecules in the sample had been removed to the minimum. This results was similar to the observations of Rafique and Nasir (2013) in an earlier study.

X- Ray Fluorescence (XRF) results showing the chemical and oxide composition of raw and calcined eggshell produced are presented in Tables 5 and 6, respectively. The composition of elements recorded in the tables shows that the calcium oxide ratio of raw eggshell which was initially 53.265 increased to 64.305 in the catalyst (calcined eggshell) produced. The increased in ratio of calcium oxide is attributed to decomposition of eggshell above $800^{\circ} \mathrm{C}$. This agreed with earlier observations of Viayan et al. (2010). It was observed that at $700{ }^{\circ} \mathrm{C}$ for $2 \mathrm{~h}$, eggshell contains $\mathrm{CaCO}_{3}$ as major phase and $\mathrm{CaO}$ as minor phase.

\begin{tabular}{|c|c|c|c|c|c|c|}
\hline & & \multicolumn{4}{|c|}{ Table 3: Classification of wavenumber for egg shell using FTIR analysis } & \\
\hline & & \multicolumn{2}{|c|}{ Raw eggshell wavenumber $\left(\mathrm{cm}^{-1}\right)$} & \multicolumn{2}{|c|}{ Calcined eggshell wavenumber $\left(\mathrm{cm}^{-1}\right)$} & \\
\hline & & \multicolumn{2}{|c|}{$3339.3-3374.2$} & \multicolumn{2}{|c|}{$3407.3-3355.1$} & \\
\hline & & \multicolumn{2}{|c|}{2973.5} & \multicolumn{2}{|c|}{2995.1} & \\
\hline & & \multicolumn{2}{|c|}{$2827.7-2591.8$} & \multicolumn{2}{|c|}{$2899.2-2712.9$} & \\
\hline & & \multicolumn{2}{|c|}{$1790.4-1645.7$} & \multicolumn{2}{|c|}{$1802.5-1608.6$} & \\
\hline & & \multicolumn{2}{|c|}{$982.3-862.3$} & \multicolumn{2}{|c|}{$1066.2-871.9$} & \\
\hline & \multicolumn{5}{|c|}{ Table 4: Result of absorption wavelength capacity for eggshell using FTIR } & \\
\hline $\mathbf{S} / \mathbf{N}$ & $\begin{array}{l}\text { Raw eg } \\
\text { number }\end{array}$ & $\begin{array}{l}\text { shell Wave } \\
\left(\mathrm{cm}^{-1}\right)\end{array}$ & $\begin{array}{l}\text { Calcined egg shell } \\
\text { wave number }\left(\mathrm{cm}^{-1}\right)\end{array}$ & Residual & Band assignment and remark & $\begin{array}{l}\text { Shift in } \\
\text { peak }\end{array}$ \\
\hline 1 & 3339.3 & & 3407.3 & +68 & $\mathrm{O}$-- H stretching vibration & Upward \\
\hline 2 & 3374.2 & & 3355.1 & -19.1 & $\mathrm{O}$-- $\mathrm{H}$ stretching vibration & downward \\
\hline 3 & 2973,5 & & 2995.1 & +21.6 & $\mathrm{C}$-- H stretching vibration & Upward \\
\hline 4 & 2827.7 & & 2899.2 & 71.5 & $\mathrm{C}$-- $\mathrm{H}$ stretching vibration & Upward \\
\hline 5 & 2591.8 & & 2712.9 & +120.1 & C -- O stretching vibration & Upward \\
\hline 6 & 1790.4 & & 1802.5 & +12.1 & $\mathrm{C}=\mathrm{O}$ vibration & Upward \\
\hline 7 & 1645.7 & & 1608.6 & -37.1 & $\mathrm{C}=\mathrm{C}$ vibration & Downward \\
\hline 8 & 982.3 & & 1066.2 & +83 & $\mathrm{C}=\mathrm{C}$ vibration & Upward \\
\hline 9 & 862.3 & & 871.9 & +9.6 & $\mathrm{C} \equiv \mathrm{C}$ vibration & Upward \\
\hline
\end{tabular}

It was observed that water and organic materials were removed below $600{ }^{\circ} \mathrm{C}$ but carbon dioxide was lost between $700-800^{\circ} \mathrm{C}$. The Loss on Ignition (L.O.I.) of the raw eggshell was $57.5 \%$ and decreased by $5.4 \%$ in the catalyst. The decrease in L.O.I. after calcination could be attributed to dehydroxylation of the catalyst during production process as observed by Viayan et al. (2010)
Biodiesel Yield from SAS: The results of transesterification are presented in Table 7. The maximum biodiesel yield of $90 \%$ was obtained at reaction temperature of $65^{\circ} \mathrm{C}$ and time of $120 \mathrm{~min}$, while the minimum yield of $70 \%$ was obtained at temperature of $55^{\circ} \mathrm{C}$ and time of $60 \mathrm{~min}$ The percentages of biodiesel yield obtained from SASO transesterification in this study showed that sand apple 
is promising oil for biodiesel production as compared with other vegetable oil crop such as soybean (20\%), jatropha (99\%), sunflower (43\%) and canola (40\%) as earlier obtained by Viayan et al. (2010).

Table 5: Result of eggshell Chemical Composition using XRF

\begin{tabular}{lll}
\hline $\begin{array}{l}\text { Elemental } \\
\text { composition }\end{array}$ & $\begin{array}{l}\text { Raw } \\
\text { eggshell }\end{array}$ & $\begin{array}{l}\text { calcined } \\
\text { eggshell }\end{array}$ \\
\hline $\mathrm{Al}$ & 0.313 & 0.421 \\
$\mathrm{~L} . \mathrm{O} . \mathrm{I}$ & 57.502 & 52.109 \\
$\mathrm{Si}$ & 0.602 & 0.493 \\
$\mathrm{P}$ & 1.254 & 0.117 \\
$\mathrm{~S}$ & 1.867 & 0.591 \\
$\mathrm{Cl}$ & 0.117 & 0.081 \\
$\mathrm{~K}$ & 0.173 & 0.101 \\
$\mathrm{Ca}$ & 38.046 & 45.932 \\
$\mathrm{~V}$ & 0.01 & 0.011 \\
$\mathrm{Fe}$ & 0.029 & 0.026 \\
$\mathrm{Sr}$ & 0.064 & 0.07 \\
$\mathrm{Ba}$ & 0.022 & 0.037 \\
\hline \multicolumn{3}{c}{ L.O.I $=$ Loss on Ignition }
\end{tabular}

Table 6: Oxide composition of the raw and calcined eggshell

\begin{tabular}{lll}
\hline $\begin{array}{l}\text { Oxide } \\
\text { composition }\end{array}$ & $\begin{array}{l}\text { Raw } \\
\text { eggshell }\end{array}$ & $\begin{array}{l}\text { Calcined } \\
\text { eggshell }\end{array}$ \\
\hline $\mathrm{Fe}_{2} \mathrm{O}_{3}$ & 0.041 & 0.037 \\
$\mathrm{MnO}$ & $\mathrm{NP}$ & 0.014 \\
$\mathrm{CaO}$ & 53.265 & 64.305 \\
$\mathrm{Al}_{2} \mathrm{O}_{3}$ & 0.591 & 0.795 \\
$\mathrm{SiO}_{2}$ & 1.289 & 1.056 \\
\hline \multicolumn{3}{c}{$N P=$ Not Present }
\end{tabular}

Variation in biodiesel yield values presented in Tables 6 indicates the temperature and time of reaction considerably affected the sand apple biodiesel yield. The Analysis of Variance (ANOVA) of biodiesel yield from SASO transesterification using calcined eggshell as catalyst is shown in Table 8 . Values of "prob $>\mathrm{F}$ less than 0.05 indicate the model terms are significant and values greater than 0.10 indicate the model term are not significant.

Table 7: Results of experimental design for transesterification of SASO

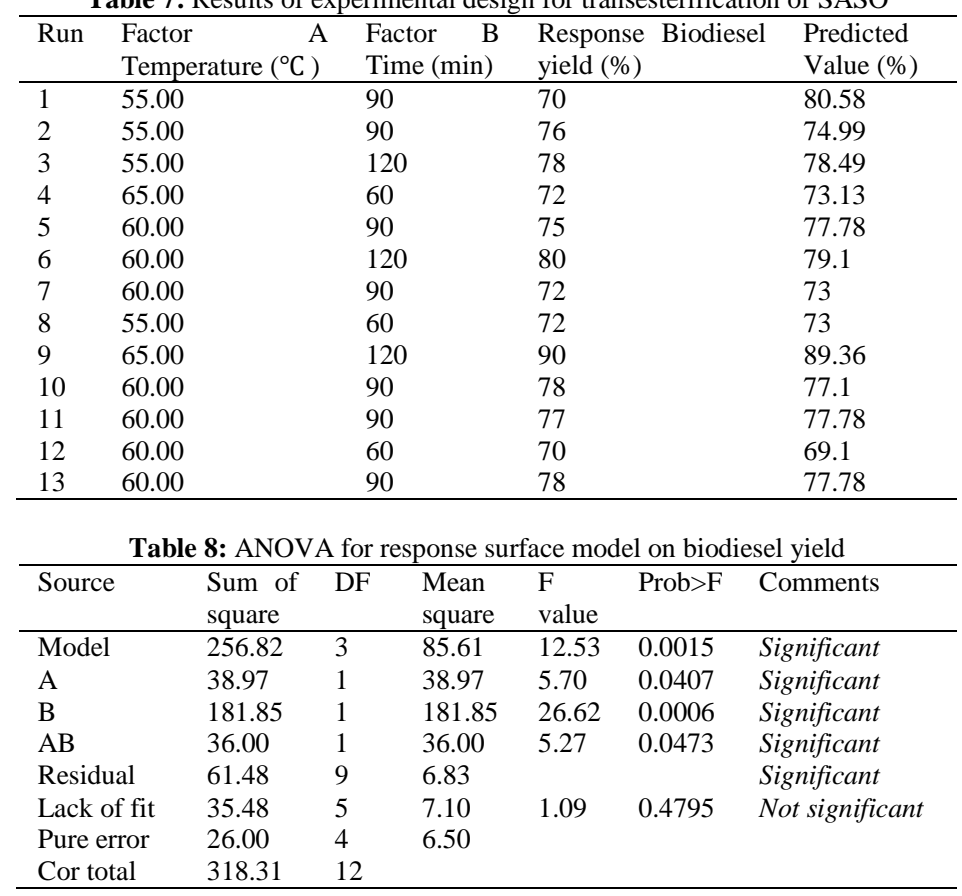

In this case $\mathrm{A}, \mathrm{B}$ and $\mathrm{AB}$ are the significant model terms. The "lack of fit F-value of 1.09 implies that the lack of fit is not significant relative to the pure error. There is a $47.95 \%$ chance that a "Lack of fit F-value" this large would occur. Standard deviation of 2.61, mean of 76.77; C.V of 3.40; $R^{2}$ of 0.8068 ; Adjusted $R^{2}$ of 0.7425 ; predicted $R^{2}$ of 0.5122 , and adequate precision of 11.531 were obtained. The ratio of 11.531 obtained in this study indicated an adequate signal and this model can be used to navigate the design space. The final empirical model equation in terms of coded factor for the yield is given in Equation 2:

$$
B D_{y}=76.77-2.21+4.77 B-3.00 A B
$$

Where: $B D_{y}=$ Biodiesel Yield; $\mathrm{A}=$ Temperature; $\mathrm{B}$ $=$ Time

From the coded factor, it can be seen that A (temperature) has negative coefficient which implies that increase in temperature would lead to decrease in yield, while B (time) has positive coefficient implying that increase in time would lead to increase in yield. Figure 3 shows the 3-D response surface plot representing the effect of temperature and time while keeping the mole ratio constant. The curvature nature 
of the surface plot indicates effect of mutual interaction between time and temperature. The 3-D plot of yield indicated mutual interaction effect of temperature and time on biodiesel yield also showed that an increase in time will lead to increase in biodiesel yield. The results of the diagnostic case studies for biodiesel yield were shown in Table 9 and Figure 4. The actual values on the table represent the amount of biodiesel yield from SASO while the predicted values represent the values from the model equation.

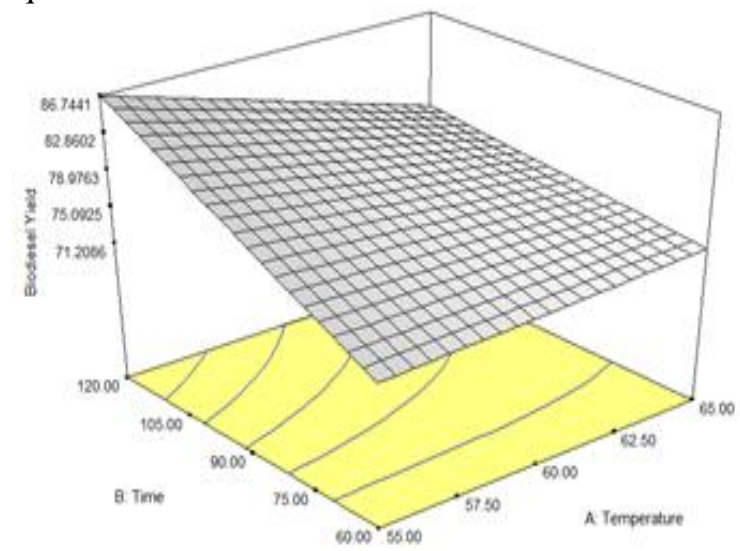

Fig 3: 3-D plot of yield with respect to temperature and time

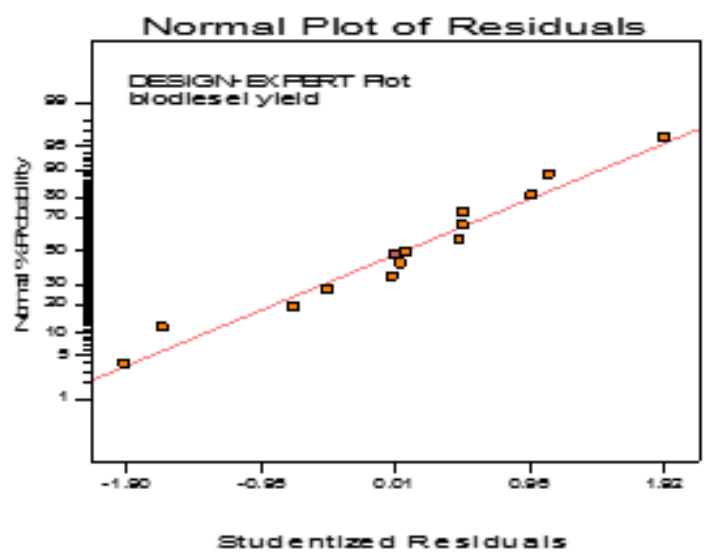

Fig 4: Biodiesel yield plot of residual

\begin{tabular}{llll}
\multicolumn{4}{l}{ Table 9: Diagnostic case studies for yield (\%) } \\
\hline $\begin{array}{l}\text { Standard } \\
\text { order }\end{array}$ & $\begin{array}{l}\text { Actual } \\
\text { value }\end{array}$ & $\begin{array}{l}\text { Predicted } \\
\text { value }\end{array}$ & Residual \\
\hline 1 & 72.00 & 71.21 & 0.79 \\
2 & 72.00 & 72.79 & -0.79 \\
3 & 90.00 & 86.74 & 3.26 \\
4 & 78.00 & 76.33 & 1.67 \\
5 & 80.00 & 79.89 & 0.11 \\
6 & 76.00 & 73.65 & 2.35 \\
7 & 70.00 & 70.03 & -0.027 \\
8 & 80.00 & 83.51 & -3.51 \\
9 & 75.00 & 76.77 & -1.77 \\
10 & 78.00 & 76.77 & 1.23 \\
11 & 77.00 & 76.77 & 0.23 \\
12 & 78.00 & 76.77 & 1.23 \\
13 & 72.00 & 76.77 & -4.77 \\
\hline
\end{tabular}

The residual showed the deviation of the actual from the predicted values. The negative value of the residual indicates that the predicted value is greater than the actual value while the positive value implies that the actual value is greater than the predicted value as observed by Viayan et al. (2010).

Effect of reaction temperature on biodiesel yield from SASO: Table 6 above presents the reaction temperature and time. The rate of reaction temperature is indispensable and need to be controlled in the transesterification process. Generally, the rate of reaction temperature used was below the alcohol boiling point $\left(78^{\circ} \mathrm{C}\right)$ so as to prevent its evaporation during transesterification reaction. Figure 6 shows that when the reaction temperature increased, the yield of ethyl ester of SASO also increased. At low reaction temperature of $55^{\circ} \mathrm{C}$, the free fatty acid conversion of $60 \%$ was achieved until it reaches optimum temperature of $65^{\circ} \mathrm{C}$ when $90 \%$ of biodiesel yield was obtained. The conversion did not improve much with further increase in temperature which means that the reaction temperature attained the equilibrium position at $65^{\circ} \mathrm{C}$. Figure 6 can testify the suitable reaction temperature for conversion of free fatty acid was $65^{\circ} \mathrm{C}$.

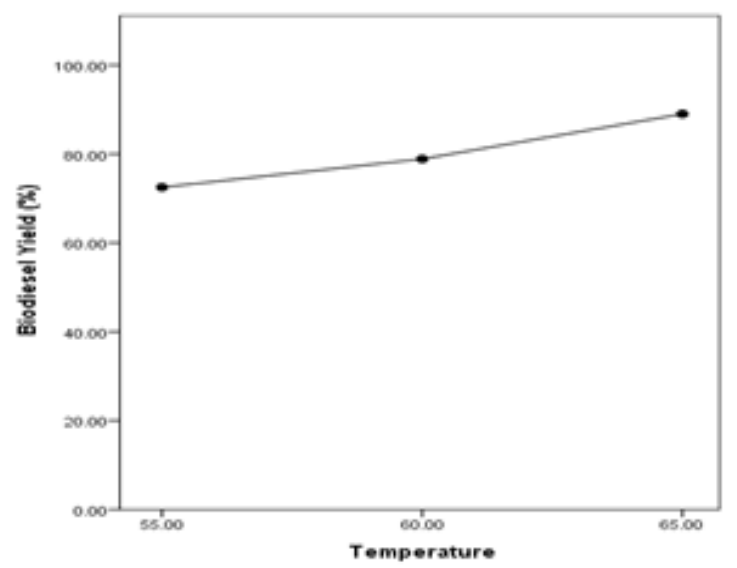

Fig 6: Effect of reaction temperature on biodiesel yield

Effect of reaction time on biodiesel yield: The influence of reaction time is presented in Figure 7 . The influence of reaction time is very important in the transesterification of free fatty acid. The minimum of $70 \%$ yield of biodiesel was obtained when the time expended was $60 \mathrm{~min}$. It was observed that the yield of conversion of free fatty acid of was $90 \%$ when reaction time increased to $120 \mathrm{~min}$ and SAEE keep increasing when the time increased. The yield of $80 \%$ was observed when reaction time increased to an interval of $30 \mathrm{~min}$. The equilibrium conversion of FFA obtained for any further increase in reaction time to 120 min was $90 \%$. Any further increase in time did not improve but rather decreased the yield. 


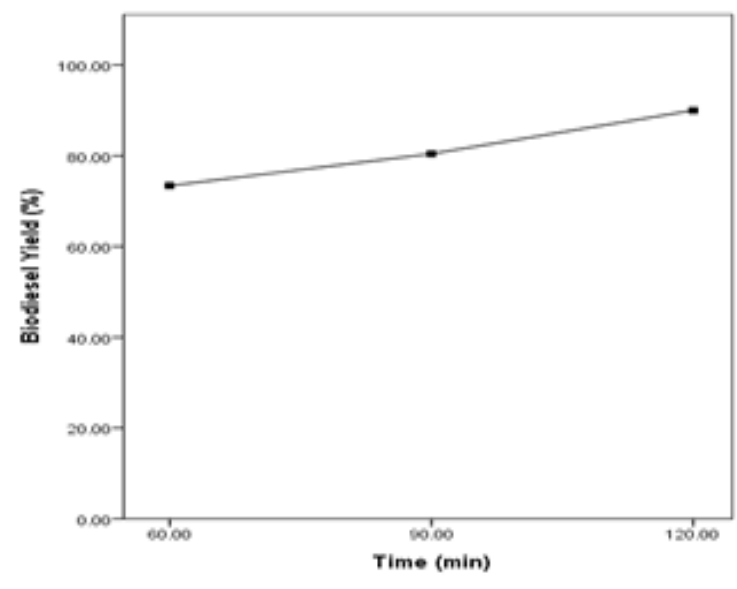

Fig 7: Effect of reaction time on biodiesel yield

Conclusion: This study characterized heterogeneous catalyst (using eggshell) from the transesterification of sand apple (parinari polyandra B.) biodiesel using solvent extraction method. The surface properties (absorption wave number and calcium oxide composition) of the raw and calcined eggshell were characterized using FTIR and XRF under the Response Surface Methodology at different temperature and time. The study also established that both temperature and time has significant effects on biodiesel yield obtained from SASO at 5\% level of significance.

\section{REFERENCES}

Alamu, OJ; Waheed, MA; Jekayinfa, SO. (2007). Biodiesel Production from Nigeria Palm-Kernel Oil; Effect of $\mathrm{KOH}$ concentration on yield; Journal on Energy for Sust. Dev. XI: 77-82.

Feunte, E; Menendez, IA; Dyez, MA; Sau''rez, D; Mountes-Moran, MA (2003). Infrared Sectroscopy Carbon Materials. A Quantum Chemical study of Model Compounds. Journal of phy. chem., 107:6350-6359.

Gerpen, J; Shanks, B; Pruszko, R (2004) Biodiesel production technology, National Renewable Energy Laboratory. Sub-contractor report, NREL/SR- 92: 510-36244.

Kusdiana, D; Saka, S (2007). Biodiesel fuel for diesel substitute prepared by catalyst free supercritical methanol. Kyoto - u.ac.jp. 80:123-125.

Niju, S; Meera, KM; Begum, S; Anantharaman, N (2004). Modification of eggshell and its application in biodiesel production. Sc journal of Saudi chem soc. 18:702-706.

Oniya, OO (2010). Production of Biodiesel from Loofah and Groundnut oil. Phd Thesis, Department of Agricultural and Environmental Engineering, University of Ibadan Nigeria. 1- 176.

Oniya, OO; Bamgboye, AI (2014). Production of biodiesel from groundnut (Arachis hypogea, L.) oil. Agric. Eng. Intern. CIGR Journal 16: 143.

Rafique, N; Nasir, S. (2013). Metal removal from waste water using environmentally friendly biomaterials: $f_{-}$- vo vicuuve and eco- friendly technique. Journal of chem. \& environ. Eng. 4: 210.

Roger, AK; Hoffman, DS; Bam, N; Peterson, CL; Down, DC (2005). Transesterification Process to Manufacture Ethyl Ester of Rape Seed Oil. Department of Chemical Engineering, University of Idaho, Moscow, I.D. 83843.1-38

Shruti, GC; Kulkarni, KS; Kulkarni, AD; Nijraj, S (2012). Toppan solid heterogeneous Catalysts for production of biodiesel from trans-esterification of triglycerides with methanol. Journal chem. \& pharm. 2(1): 8-14.

Viayan, B; Dimitrijevic, NM; Rajh, T; Gray, K 2010. Effect of calcination temperature on the photocatalytic reduction and oxidation processes of hydrothermally synthesized Titania nanotubes. Journal US dept. of energy. 114 (30): 1932 - 7447.

Vyas, AP; Subrahmanyam, N; Patel, PA (2009). Production of biodiesel through transesterification of Jatropha oil using $\mathrm{KNO}_{3} / \mathrm{Al}_{2} \mathrm{O}_{3}$ solid catalyst. Fuel. 88(4): 625 - 628.

Wei, Z; Xu, C; Li, B (2004) Application of waste eggshell as low cost solid catalyst for biodiesel production, Bires. Technol., 100: 2883-2885. 